Original Research Paper

\title{
The Utilization of Medicinal Plants to Cure Gastrointestinal Disorders by The Dayak Muara Tribe in Kuala Dua Village, Sanggau Regency
}

\author{
Fathul Yusro" ${ }^{*}$, Yeni Mariani ${ }^{1}$, Evy Wardenaar ${ }^{1}$ \\ ${ }^{1}$ Forestry Department, Forestry Faculty, Tanjungpura University, Pontianak, Indonesia
}

\author{
Article History \\ Received : May 03 ${ }^{\text {th }}, 2021$ \\ Revised : May $18^{\text {th }}, 2021$ \\ Accepted : May $27^{\text {th }}, 2021$ \\ Published : June $02^{\text {th }}, 2021$ \\ *Corresponding Author: \\ Fathul Yusro, \\ Forestry Faculty, Tanjungpura \\ University, Pontianak \\ Email: fathulyusro@gmail.com
}

\begin{abstract}
People use medicinal plants to treat various diseases, such as gastrointestinal disorders. The study aims to analyze the use of medicinal plants to cure gastrointestinal disorders by the Dayak Muara tribe in Kuala Dua Village, Sanggau Regency. The sampling method was purposive sampling, with the number of respondents was $10 \%$ of the total number of households in Kuala Dua Village (91 respondents). The information regarding the medicinal plants used by the Dayak Muara tribe to cure gastrointestinal disorders such as diarrhea, intestinal worms, nausea and vomiting, constipation, gastric, flatulence, and stomachache was collected. Furthermore, data obtained were analyzed for the use-value (UV), informant consensus factor (ICF), and fidelity level (FL). The result of this study shows that the Dayak Muara tribe in Kuala Dua village, Kembayan District, has used a total of 17 species of medicinal plants to cure gastrointestinal disorders. Curcuma longa shows the highest use value or UV (0.96), followed by Psidium guajava (0.89) and Zingiber officinale (0.45). Category of diseases with the highest value of ICF are diarrhea (0.98), followed by gastric, stomachache, nausea, and vomiting (0.96), constipation (0.94), intestinal worms and flatulence (0.88). The plants with the highest fidelity level (FL) are Allium sativum, Cymbopogon citratus and Centella asiatica for gastric (100), Areca catechu for constipation (100), Moringa oleifera, and Theobroma cacao (100) for stomachache.
\end{abstract}

Keywords: Dayak Muara, medicinal plants, gastrointestinal disorders

\section{Introduction}

Since a long time ago, people of West Kalimantan province use many plants for health surveillance, and it is part of their indigenous culture. Nowadays, this culture is only orally inherited by younger generations. Therefore, in the future, the knowledge of medicinal plants may disappear concomitant with the rapid development of modern medicine.

Researchers have made various attempts to document the knowledge possessed by the community. One of which is through the ethnobotanical study of medicinal plants in the community in Sanggau Regency, West Kalimantan, such as reported by Haryono et al., (2013) in Mengkiang Village, Sari et al., (2014) in Serambai sub-village, Albertus et al., (2015) in Mount Semarong Customary Forest, Rahman et al., (2019) in Beringin Village,
Ningsih et al., (2020) in Bunut Village and Pradita et al., (2021) in Pengadang Village. The people in these villages consist of various tribes, one of which is the Dayak tribe.

The Dayak tribe, which is the largest part of the tribes in West Kalimantan, is known to have high knowledge of medicinal plants. The previous studies had been conducted in many locations such as in the Dayak Seberuang (Takoy et al., 2015), in Dayak Darok and Bukat (Yusro et al., 2014), in Dayak Jangkang Tanjung (Sari et al., 2014), in Dayak Tabun, (Wildayati et al., 2016), in Dayak Kanayant (Riadi et al., 2019; Sari et al., 2021), in Dayak Iban (Yusro et al., 2019), in Dayak Desa (Supiandi et al., 2019; Yusro et al., 2020). Several other Dayak tribes in West Kalimantan, especially in Sanggau District, still have not conducted studies related to the use of medicinal plants, one of which is the Dayak Muara tribe in Kuala Dua village, 
Sanggau Regency. The traditions and culture of the Dayak Muara tribe are still closely attached to their lives, one of which is related to the use of traditional medicine made from plants.

The local community used medicinal plants taken from the forest or the surrounding environment to treat various health problems, including gastrointestinal disorders. Several diseases are classified as gastrointestinal disorders, namely diarrhea, dysentery, intestinal worms, nausea and vomiting, constipation, and abdominal pain (Tariq et al., 2015). The community often faced those diseases, and it may be closely related to the low level of community sanitation. Indonesian basic health research in 2019 states that in Indonesia one of the diseases belongs to gastrointestinal disorder, namely diarrhea has a relatively high prevalence which is $6.8 \%$ (Balitbangkes RI, 2019).

Gastrointestinal disorders are part of the digestive system disorders. Previous research reported that the West Kalimantan community had used medicinal plants to treat the digestive system disorder (Yusro et al., 2019; Ningsih et al., 2020). The Dayak Iban tribe in Kapuas Hulu Regency uses 21 species (Yusro et al., 2019), and people in Bunut Village, Sanggau Regency, uses 31 species of medicinal plants (Ningsih et al., 2020).

Public knowledge of medicinal plants of the Dayak Muara tribe, especially those related to gastrointestinal disorder diseases, has not been documented. Therefore, the data collection on the species of plants used is essential to be done as part of efforts to save the knowledge of medicinal plants. Thus, the preservation and the optimal utilization of plants to maintain public health can be determined. This study aims to analyze the use of medicinal plants by the Dayak Muara tribe in Kuala Dua village, Sanggau Regency, West Kalimantan, especially their use to treat gastrointestinal disorders.

\section{Materials and Method}

\section{Research time and site}

The research was carried out in MarchApril 2020. The research location was in Kuala
Dua Village, Sanggau District, West Kalimantan (Fig. 1).

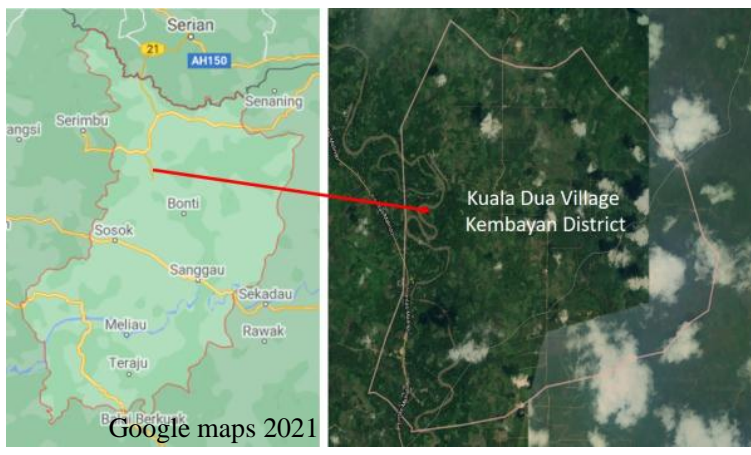

Figure 1. Research location in Kuala Dua Village, Kembayan District, Sanggau Regency

\section{Data Collection}

This research was conducted by using a survey method. The respondents were selected using purposive sampling. The criteria for respondents are: (1) A the Dayak Muara tribe; (2) residing in Kuala Dua Village, Sanggau Regency at least five years, and (3) aged more than 17 years old. The number of respondents in this study was $10 \%$ of the total number of households in Kuala Dua Village or as many as 91 respondents.

We used a questionnaire as a guideline in the interview. The plant to treat gastrointestinal disorders (diarrhea, dysentery, intestinal worms, nausea and vomiting, constipation, gastric, flatulence, and stomachache), the part of the plant used, the method of processing, the method of administration, and the potion ingredients (single or mixed) were asked to respondents. The plants mentioned by the respondents were then identified in the field to determine their scientific names.

\section{Data analysis}

We analyzed data obtained by using use value (UV), informant consensus factor (ICF), and fidelity level (FL), which refers to Tangjitman et al., (2015).

$$
\mathrm{UV}=\sum \mathrm{U} / \mathrm{n}
$$

$\mathrm{UV}=$ Use Value

$\mathrm{U} \quad=$ Number of reports

$\mathrm{n} \quad=$ Total of respondent 


$$
\mathrm{ICF}=(\mathrm{Nur}-\mathrm{Nt}) /(\mathrm{Nur}-1)
$$

ICF = Informant consensus factor

Nur $=$ Number of reports for a particular disease category

$\mathrm{Nt}=$ Number of taxa or plant used in a particular disease category

$$
\mathrm{FL}(\%)=(\mathrm{Np} / \mathrm{N}) * 100
$$

$\mathrm{FL} \quad=$ Fidelity level (\%)

$\mathrm{Np} \quad=$ Number of use report of a plant species for a particular disease category

$\mathrm{N} \quad=$ Total use report of a plant species

\section{Result and Discussion}

\section{Respondent characteristics}

The Dayak Muara tribe in Kuala Dua Village, Kembayan District, Sanggau Regency, is still aware in utilizing medicinal plants in their environment as medicinal ingredients, especially for handling gastrointestinal disorders. Figure 2 presents the percentage of respondent characteristics of Dayak Muara in Kuala Dua Village. The majority of the Dayak Muara people are Catholics (96.7\%) (Fig. 2D). Their knowledge of medicinal plants generally comes from parents $(79.82 \%)$ (Fig. 2H). It is passed from one generation to the next generation. The result showed that women of Dayak Muara $(50.55 \%)$ possess higher knowledge more than men $(49.45 \%)$ (Fig. 2A), especially at the age of 30-50 years $(62.64 \%)$ and $>50$ years $(30.77 \%)$ (Fig. 2B).

In this study, we found that there were three levels of education of the respondents, and most of the respondents who know the medicinal plants are in elementary education level $(42.86 \%)$, followed by junior high school level $(28,57 \%)$, and senior high school $(23,08 \%)$ (Fig. $2 \mathrm{C})$. The high percentage of occupation are housewives $(41.76 \%)$ and farmers $(38.46 \%)$. In Fig. 2E, most of their income rates range from Rp. 1-3 million, with 3-4 family members (Fig. 2F).

In this study, we found that women of Dayak Muara had higher knowledge of medicinal plants than men. A similar result had been reported by several researchers such as De Almeida et al. (2012) in the community in
Atlantic forest from Northeastern Brazil, and Adnan et al., (2015) in Pashtun's tribe and Bourhia et al., (2019) in Greater CasablancaMorroco show that women have a high level of knowledge of medicinal plants.

It is assumed that women's high knowledge of medicinal plants is due to their significant responsibility to maintaining family health (Torres-Avilez et al. 2016). Moreover, women have active participation in cultivating medicinal plants in the yard where they live (De Almeida et al., 2012).

Among the Dayak Muara tribe in Kuala Dua village, older respondents have high knowledge of the medicinal plant. A similar result was reported by Abera (2014) in Oromo people at Ghimbi district Southwest Ethiopia, and Bourhia et al., (2019) in Greater Casablanca-Morroco. According to Silva et al., (2011), the high knowledge of older people may due to their experience and frequent direct contact with various plants in their environment. Moreover, they have an excellent opportunity to learn about medicinal plant knowledge from their parents. Usually, the older people had higher knowledge of medicinal plants than the current generation.

Adnan et al., (2015) reported that the majority of medicinal users have low education levels, as we found in Dayak Muara tribe in Kuala Dua Village. It assumed that people with lowlevel education levels, especially women, have high knowledge of medicinal plants. It may seem because, in rural areas, women get less education than men. Women are considered prospective mothers or wives who must assist with household affairs. Some of the factors that lead to a high level of community dependence on medicinal plants namely low levels of education, low levels of income, and inadequate medical facilities (Adnan et al., 2015).

Adnan et al., (2015) reported that most medicinal plant users are women whose main job is housewives in the Khyber Pakhtunkhwa region of Pakistan. This condition is similar to our findings in the Dayak Muara tribe in Kuala Dua Village. Domestic work is generally the responsibility of women, and they have considerable authority in maintaining and maintaining family health (Torres-Avilez et al., 2016). 

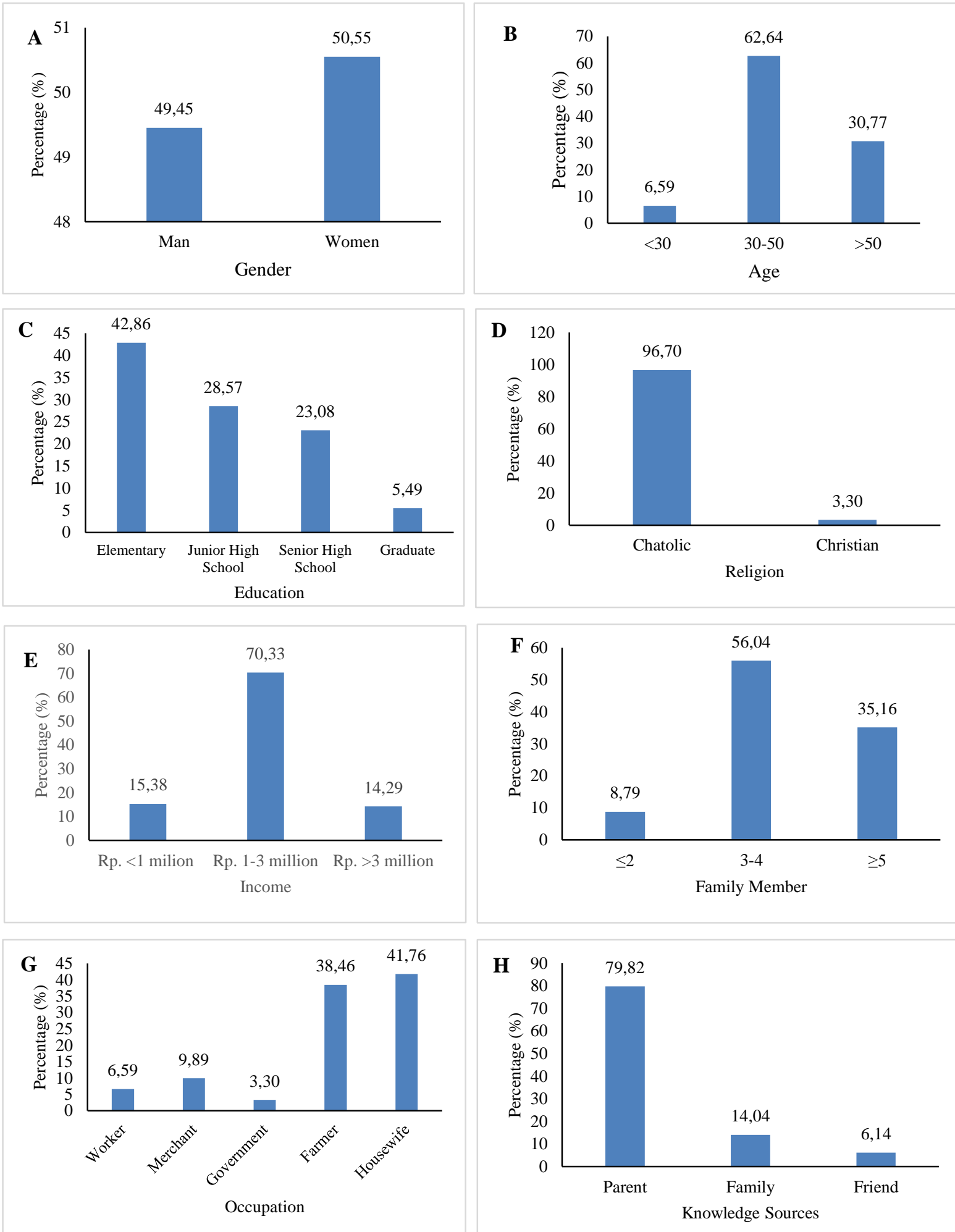

Figure 2. The percentage of respondent characteristics of Dayak Muara in Kuala Dua Village, Kembayan District, Sanggau Regency 
Fathul Yusro, et al. (2021). Jurnal Biologi Tropis, 21 (2): 416 - 426

DOI: http://dx.doi.org/10.29303/jbt.v21i2.2638

Table 1. Medicinal plants to treat gastrointestinal disorders used by the Dayak Muara tribe

\begin{tabular}{|c|c|c|c|c|c|c|}
\hline No. & Local Name & Botanical Name & Family & Habitus & Indications & Plant parts usage \\
\hline 1 & Kunyit & Curcuma longa & Zingiberaceae & Herb & Gastric, stomachache, flatulence & Rhizome \\
\hline 2 & Serai & Cymbopogon citratus & Poaceae & Herb & Gastric & Leaves \\
\hline 3 & Jahe & Zingiber officinale & Zingiberaceae & Herb & Nausea and vomiting, gastric and flatulence & Rhizome \\
\hline 4 & Temulawak & Curcuma zanthorrhiza & Zingiberaceae & Herb & $\begin{array}{l}\text { Gastric, flatulence, nausea and vomiting, } \\
\text { intestinal worms }\end{array}$ & Rhizome \\
\hline 5 & Bangle & Zingiber casumounar & Zingiberaceae & Herb & Gastric and stomachache & Rhizome \\
\hline 6 & Bawang putih & Allium sativum & Amaryllidaceae & Herb & Stomachache & Bulb \\
\hline 7 & Bawang merah & Allium сера & Amaryllidaceae & Herb & Diarrhea and gastric & Bulb \\
\hline 8 & Nangka belanda & Annona muricata & Annonaceae & Shrub & Flatulence, stomachache, diarrhea & Leaves \\
\hline 9 & Jambu biji & Psidium guajava var pyrifera & Myrtaceae & Shrub & Gastric, diarrhea and constipation & Leaves, fruit, stem \\
\hline 10 & Pegagan & Centella asiatica & Mackinlayaneae & Herb & Gastric & Leaves \\
\hline 11 & Mengkudu & Morinda citriolia & Rubiaceae & Shrub & Stomachache and gastric & Leaves \\
\hline 12 & Pisang & Musa acuminata & Musaceae & Herb & Constipation and gastric & Fruit \\
\hline 13 & Pinang & Areca catechu & Arecaceae & Tree & Constipation and gastric & Fruit \\
\hline 14 & Pepaya & Carica papaya & Caricaceae & Shrub & Gastric and constipation & Fruit \\
\hline 15 & Kencur & Kaempferia galanga & Zingiberaceae & Herb & $\begin{array}{l}\text { Nausea and vomiting, gastric, stomachache } \\
\text { and intestinal worms }\end{array}$ & Rhizome \\
\hline 16 & Koko & Theobroma cacao $\mathrm{L}$ & Malvaceae & Shrub & Stomachache & Fruit \\
\hline 17 & Kelor & Moringa oleifera & Moringaceae & Shrub & Stomachache & Leaves \\
\hline
\end{tabular}


Fathul Yusro, et al. (2021). Jurnal Biologi Tropis, 21 (2): 416 - 426

DOI: http://dx.doi.org/10.29303/jbt.v21i2.2638

Table 2. The processing technique, utilization method, usage form and use value of the medicinal plants to treat gastrointestinal disorders used by the Dayak Muara tribe

\begin{tabular}{|c|c|c|c|c|c|c|}
\hline No. & Local Name & Processing Technique & Utilization Method & Usage Form & $\sum \mathbf{U}$ & $\begin{array}{c}\text { Use value } \\
\text { (UV) }\end{array}$ \\
\hline 1 & Kunyit & Mashed, boiled, grated & Patched, drunk & Single, mixed & 87 & 0.96 \\
\hline 2 & Serai & Boiled & Drunk & Mixed & 5 & 0.05 \\
\hline 3 & Jahe & Boiled & Drunk & Single & 41 & 0.45 \\
\hline 4 & Temulawak & Boiled & Drunk & Single & 15 & 0.16 \\
\hline 5 & Bangle & Boiled & Patched, drunk & Mixed & 14 & 0.15 \\
\hline 6 & Bawang putih & Mashed & Patched, rubbed & Single & 21 & 0.23 \\
\hline 7 & Bawang merah & Mashed & Patched, drunk & Single & 30 & 0.33 \\
\hline 8 & Nangka belanda & Boiled & Drunk & Single & 7 & 0.08 \\
\hline 9 & Jambu biji & Unprocessed, mashed, boiled & Patched, ate, Drunk, gargled & Mixed & 81 & 0.89 \\
\hline 10 & Pegagan & Boiled & Drunk, gargled & Single & 27 & 0.30 \\
\hline 11 & Mengkudu & Boiled & Drunk & Single & 41 & 0.45 \\
\hline 12 & Pisang & Unprocessed & Ate & Single & 36 & 0.40 \\
\hline 13 & Pinang & Boiled & Drunk & Mixed & 7 & 0.08 \\
\hline 14 & Pepaya & Unprocessed & Ate & Single & 31 & 0.34 \\
\hline 15 & Kencur & Mashed, boiled, grated & Patched, drunk & Mixed & 26 & 0.29 \\
\hline 16 & Koko & Boiled & Drunk, gargled & Single & 11 & 0.12 \\
\hline 17 & Kelor & Boiled & Drunk & Single & 7 & 0.08 \\
\hline
\end{tabular}


The medicinal plants to cure gastrointestinal disorders and their use value (UV)

Until now, the Dayak Muara people in Kuala Dua Village, Kembayan District, Sanggau Regency, still have knowledge related to the use of plants as ingredients for gastrointestinal disorders. The result found that all respondents $(100 \%)$ know about the benefits of plants around their environment to treat various diseases that they often experience, especially those related to disorders treatments. The Dayak Muara people knowledge of medicinal plants ranges from 2-11 species and an average of 6 species. Table 1 and 2 presents the medicinal plants to treat gastrointestinal disorders used by the Dayak Muara tribe, and it processing technique and utilization method.

This study documented a total of 17 species of medicinal plants used by Dayak Muara to treat gastrointestinal disorders (Table 1). The medicinal plant knowledge of Dayak Muara in Kuala Dua village is lower than other tribe, such as Dayak Iban (21 species) (Yusro et al., 2019) and people of Bunut village, Sanggau Regency (31 species) (Ningsih, et al., 2020). The knowledge of Dayak Muara tribe also lower than Karen tribe, Thailand, that use at total of 36 plants as ingredients in traditional medicine to treat digestive problems (Tangjitman et al., 2015). We found that there are three species of plants that have a high use value (UV), namely Curcuma longa (0.96), Psidium guajava (0.89), and Zingiber officinale (0.45) (Table 1).

The high UV value of the three plants indicates that the level of public confidence in treating diseases using these medicinal plants is relatively high. The specific uses for each plant are Curcuma longa used for ulcers, abdominal pain, flatulence; Psidium guajava to treat ulcers, diarrhea, and constipation; and Zingiber officinale for nausea and vomiting, ulcers, and flatulence. The use of these plants can be used singly or mixed.

Several plants showed moderate of UVs, such as Carica papaya (0.34), Centella asiatica (0.33), Allium cepa (0.33), Kaempferia galanga (0.29), and A. sativum (0.23). The moderate UV represented that the level of public confidence in these five species is at an intermediate level. Meanwhile, other species are categorized as low level of trust because they are rarely known or used to treat gastrointestinal disorders.
In this study, we found that the most dominant plant parts used by Dayak Muara as medicinal substances in treat gastrointestinal disorders were leaf $(38 \%)$, followed by fruit (33\%) and rhizome (19\%) (Fig. 3A). The similar results were also reported by Ningsih et al., (2020) and Yusro et al., (2020). We assume that the high level of use in leaf is due to the availability, and or easier processing method than other plant part such as roots or stems. Figure 3 presents the plant part and utilization of medicinal plants to cure gastrointestinal disorders used by Dayak Muara.

The processing techniques or the process of concocting plants for potion before being used by the Dayak Muara tribe are pretty diverse, including boiled, grated, mashed, unprocessed. The most common method and easy to do is boiled (54\%), mashed (21\%), unprocessed (17\%), and grated (8\%) (Fig. 3B). This result is supported by Ningsih et al., (2020) and Yusro et al., (2020). It is assumed that the extraction process by the boiling method has high effectiveness in removing the active substances contained in plants when compared to other methods (Sun et al. 2016), therefore the Dayak Muara people more dominantly choose this method.

The results showed that the highest percentage of utilization method of plants was drunk (50\%), followed by patched (21\%), gargled (14\%), ate (11\%), and rubbed (4\%) (Fig. 3C). A similar result was also reported by Rania et al., (2019), Ningsih et al., (2020), and Yusro et al., (2020). Drunk is an administration method with high effectiveness compares with others (Tugume et al. 2016), thus is become the primary option of Dayak Muara while treating gastrointestinal disorders. However, sometimes the administration method is adjusted to the category of disease experienced by a person.

The people of the Dayak Muara tribe dominantly use medicinal plants singly (67\%), and some are mixed (33\%) (Fig. 3D). These results align with our previous studies (Yusro et al., 2019) and Yusro et al., 2020). According to Tugume et al. (2016) the single concoction is easier to be applied in diseases treatment without asking for recipes or additional ingredients from the traditional healers. 


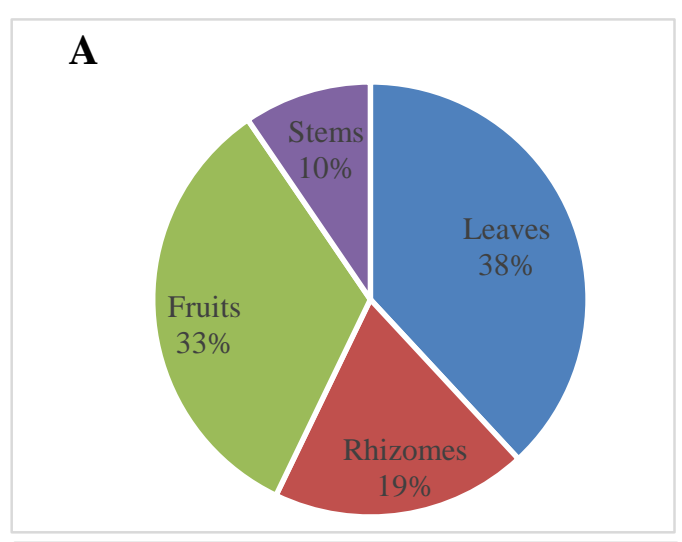

C

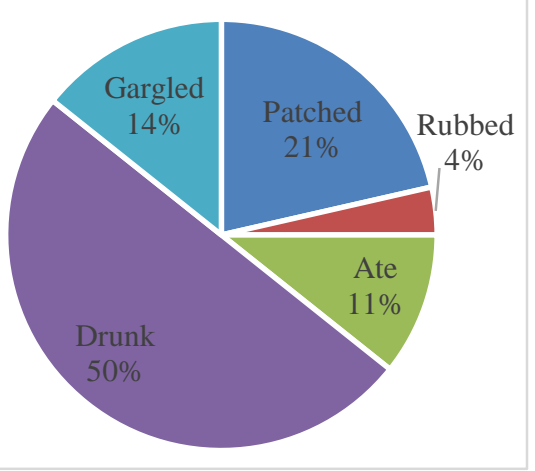

B

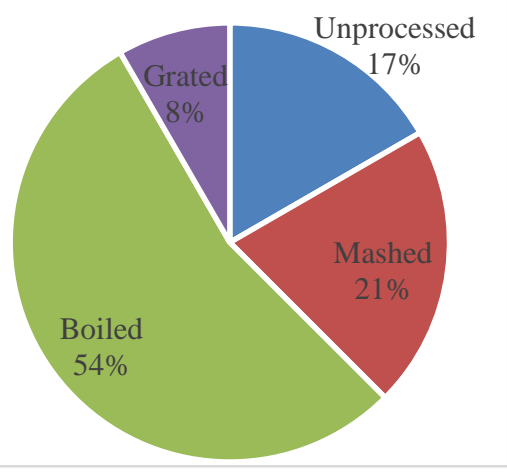

D

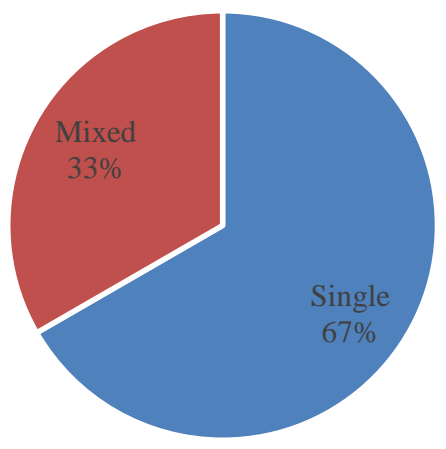

Figure 3. The percentage of plant part and utilization of medicinal plant to cure gastrointestinal disorders used by Dayak Muara in Kuala Dua Village, Kembayan District, Sanggau Regency

Table 3. Gastrointestinal disorder categories, informant consensus factors (ICF) and fidelity level (FL).

\begin{tabular}{|c|c|c|c|}
\hline No & $\begin{array}{c}\text { Disorder } \\
\text { categories }\end{array}$ & ICF & Fidelity Level (\%) \\
\hline 1 & Gastric & 0.96 & $\begin{array}{l}\text { Curcuma longa (84.04), Carica papaya (27.27), Psidium } \\
\text { guajava (4.65), Morinda citriolia (51.47), Musa acuminata } \\
\text { (37.14), Curcuma zanthorrhiza (20), Zingiber casumounar } \\
\text { (78.57), Cymbopogon citratus (100), Kaempferia galanga } \\
\text { (38.23), Allium cepa (55.55), Allium sativum (100), } \\
\text { Centella asiatica (100) }\end{array}$ \\
\hline 2 & Stomachache & 0.96 & $\begin{array}{l}\text { Curcuma longa (13.82), Kaempferia galanga (20.58), } \\
\text { Psidium guajava (53.49), A. muricata (33.33), Zingiber } \\
\text { casumounar }(21.43), \text { Morinda citriolia }(48.53) \text {, Moringa } \\
\text { oleifera (100), Theobroma cacao }(100)\end{array}$ \\
\hline 3 & Flatulence & 0.88 & $\begin{array}{l}\text { Curcuma longa (2.12), Curcuma zanthorrhiza (30), } \\
\text { Annona muricata (33.33) }\end{array}$ \\
\hline 4 & $\begin{array}{l}\text { Nausea and } \\
\text { vomiting }\end{array}$ & 0.96 & $\begin{array}{l}\text { Zingiber officinale (70.73), Kaempferia galanga (19.11), } \\
\text { Curcuma zanthorrhiza (20) }\end{array}$ \\
\hline 5 & Constipation & 0.94 & $\begin{array}{l}\text { Zingiber officinale (29.26), Psidium guajava ( } 3.1) \text {, A. } \\
\text { catechu (100), Carica papaya ( } 72.72) \text {, Musa acuminata } \\
(62.85)\end{array}$ \\
\hline 6 & Intestinal worms & 0.88 & Kaempferia galanga (20.05), Curcuma zanthorrhiza (30) \\
\hline 7 & Diarrhea & 0.98 & $\begin{array}{l}\text { Annona muricata (33.33), Allium cepa (44.44), Psidium } \\
\text { guajava (38.76) }\end{array}$ \\
\hline
\end{tabular}




\section{Informant Consensus Factor (ICF) and Fidelity Level (FL)}

This study found that the informant consensus factor values (ICF) varied widely, ranging from 0.88 to 0.98 . The highest value of ICF (0.88-1.00) indicates the best level of agreement or understanding from informants in terms of the use or efficacy of medicinal plants used (Tangjitman et al., 2015) to cure various problems/disorders in the gastrointestinal, such as diarrhea (0.98), gastritis, stomachache, nausea and vomiting, each of which had ICF (0.96), constipation (0.94) as well as intestinal worms, and flatulence (0.88). The ICF value of each disease category is presented in Table 2. Tangjitman et al. (2015) stated that a high ICF value is significant in identifying potential plants as drugs, especially for researching bioactive compounds. The results of the study reported that the species of plants that with the highest of fidelity level (FL) were Arenga catechu (100) for constipation, Moringa oleifera, and Theobroma cacao (100) for stomachache. Other plants that have a high FL value ranged from 60-85 were Curcuma longa (84.04) and Zingiber casumounar (78.57) for gastric, Zingiber officinale (70.73) for nausea and vomiting, and Carica papaya (72.72) and Musa acuminata (62.85) for constipation. The medicinal herbs used are a potential clue to the plants with high healing properties associated with certain diseases. Plants with the highest FL value can be further targeted, especially identifying bioactive compounds responsible for healing from certain diseases (Tangjitman et al., 2015).

\section{Conclusion}

Dayak Muara tribe in Kuala Dua village still using medicinal plants, especially in gastrointestinal disorders treatments. A total of 17 species were used in the treatments. Several plants have a high level of use, and it is supported by the high of community agreement and high preference of plants in particular gastrointestinal disorders category. Therefore, it is an opportunity to prove the efficacy of these plants scientifically so that in the future, the knowledge possessed by the Dayak Muara tribe can be used by the broader community.

\section{Acknowledgment}

We acknowledge the Faculty of Forestry, Tanjungpura University, for the research funding. We also thank to the village head and Dayak Muara people of Kuala Dua Sanggau Regency, who fully supported this research.

\section{References}

Abera, B. (2014). Medicinal Plants Used in Traditional Medicine by Oromo People, Ghimbi District, Southwest Ethiopia. Journal of Ethnobiology and Ethnomedicine, 10(1), 1-15. DOI: https://doi.org/10.1186/1746-4269-1040

Adnan, M., Tariq, A., Mussarat, S., Begum, S., Abdeisalam, N. M., \& Ullah, R. (2015). Ethnogynaecological Assessment of Medicinal Plants in Pashtun's Tribal Society. BioMed Research International, 2015, 1-9. DOI: https://doi.org/10.1155/2015/196475

Albertus, Dewantara, I., \& Herawatiningsih, R. (2015). Jenis dan Potensi Tumbuhan Obat pada Kawasan Hutan Adat Gunung Semarong Kecamatan Tayan Hulu Kabupaten Sanggau. Jurnal Hutan Lestari, 3(3), 446-455. https://jurnal.untan.ac.id/index.php/jmfk $\mathrm{h} /$ article/view/11379.

Balai Penelitian dan Pengembangan Kesehatan (ed.). (2019). "Riset Kesehatan Dasar 2019", Kementerian Kesehatan RI, Jakarta.

Bourhia, M., Abdelaaty, A. S., Almarfadi, O. M., Naser, F. A., Abdelmageed, W. M., Said, A. A. H., El Gueddari, F., Naamane, A., Benbacer, L., \& Khlil, N. (2019). Ethnopharmacological Survey of Herbal Remedies Used for the Treatment of Cancer in the Greater CasablancaMorocco. Evidence-Based Complementary and Alternative Medicine, 2019, 1-9.DOI: https://doi.org/10.1155/2019/1613457

De Almeida, C. D. F. C. B. R., Ramos, M. A., Silva, R. R. V., De Melo, J. G., Medeiros, M. F. T., Arajo, T. A. D. S., De Almeida, A. L. S., De Amorim, E. L. C., Alves, R. R. D. N., \& De Albuquerque, U. P. 
(2012). Intracultural Variation in the Knowledge of Medicinal Plants in an Urban-rural Community in the Atlantic Forest from Northeastern Brazil. Evidence-Based Complementary and Alternative Medicine, 2012. DOI: https://doi.org/10.1155/2012/679373

Haryono, D., Wardenaar, E., \& Yusro, F. (2013). Kajian Etnobotani Tumbuhan Obat di Desa Mengkiang Kecamatan Sanggau Kapuas Kabupaten Sanggau. Jurnal Hutan Lestari, 2(3), 427-434. https://jurnal.untan.ac.id/index.php/jmfk h/article/view/7575.

Ningsih, K., Mariani, Y., Arbiastutie, Y., \& Yusro, F. (2020). Studi Pemanfaatan Tumbuhan Obat Berpotensi Mengobati pada Penyakit Sistem Pencernaan di Kelurahan Bunut Kecamatan Kapuas Kabupaten Sanggau. Jurnal Hutan Lestari, $\quad$ 8(2), 217-228. https://jurnal.untan.ac.id/index.php/jmfk h/article/view/39782/0.

Pradita, S., Mariani, Y., Wardenaar, E., Yusro, F., Kehutanan, F., Tanjungpura, U., \& Daya, J. (2021). Pemanfaatan Tumbuhan Obat oleh Suku Dayak Paus dan Melayu untuk Perawatan Ibu dan Anak Pasca Persalinan di Desa Pengadang Kabupaten Sanggau Kalimantan Barat. Biodidaktika: Jurnal Biologi Dan Pembelajarannya, 16(1), 93-110. DOI: http://dx.doi.org/10.30870/biodidaktika. v16i1.10805

Rahman, K., Wardenaar, E., \& Mariani, Y. (2019). Identifikasi Jenis dan Pemanfaatan Tumbuhan Obat di Hutan Tembawang oleh Masyarakat Kelurahan Beringin Kecamatan Kapuas Kabupaten Sanggau. Jurnal Hutan Lestari, 7(1), 44 55.

https://jurnal.untan.ac.id/index.php/jmfk h/article/view/30996.

Rania, Yusro, F., Wardenaar, E., \& Mariani, Y. (2019). Studi Pemanfaatan Tumbuhan Obat oleh Pengobat Tradisional untuk Mengatasi Masalah Kewanitaan di Desa Masbangun Kecamatan Teluk Batang Kabupaten Kayong Utara. Jurnal Borneo Akcaya, 5(2), 84-94. http://jurnallitbang.kalbarprov.go.id/index.php/litba ng/article/download/113/95.
Riadi, R., Oramahi, H. ., \& Yusro, F. (2019). Pemanfaatan Tumbuhan Obat oleh Suku Dayak Kanayatn di Desa Mamek Kecamatan Menyuke Kabupaten Landak. Jurnal Hutan Lestari, 7(2), 905-915.

https://jurnal.untan.ac.id/index.php/jmfk h/article/view/34559.

Sari, R.P., Yusro, F., \& Mariani, Y. (2021). Medicinal Plants Used by Dayak Kanayatn Traditional Healers in Tonang Village Sengah Temila District Landak Regency. Jurnal Biologi Tropis, 21(2): 324-335.

DOI: https://doi.org/10.29303/jbt.v21i2.2557.

Sari, R. Y., Wardenaar, E., \& Muflihati. (2014). Etnobotani Tumbuhan Obat di Dusun Serambai Kecamatan Kembayan Kabupaten Sanggau Kalimantan Barat. Jurnal Hutan Lestari, 2(3), 379-387. https://jurnal.untan.ac.id/index.php/jmfk h/article/view/7309.

Silva, F. dos S., Ramos, M. A., Hanazaki, N., \& de Albuquerque, U. P. (2011). Dynamics of Traditional Knowledge of Medicinal Plants in a Rural Community in the Brazilian Semi-arid Region. Brazilian Journal of Pharmacognosy, 21(3), 382391.

DOI: https://doi.org/10.1590/S0102695X2011005000054

Supiandi, M. I., Mahanal, S., Zubaidah, S., \& Julung, H. (2019). Ethnobotany of Traditional Medicinal Plants Used by Dayak Desa Community in Sintang, West Kalimantan, Indonesia. Biodiversitas, 20(5), 1264-1270. DOI: https://doi.org/10.13057/biodiv/d200516

Takoy, D. M., Linda, R., \& Lovadi, I. (2015). Tumbuhan Berkhasiat Obat Suku Dayak Seberuang Di Kawasan Hutan Desa Ensabang Kecamatan Sepauk Kabupaten Sintang. Jurnal Protobiont, 2(3), 122128.

DOI: https://doi.org/10.26418/protobiont.v2i3 .3878

Tangjitman, K., Wongsawad, C., Kamwong, K., Sukkho, T., \& Trisonthi, C. (2015). Ethnomedicinal Plants Used for Digestive System Disorders by the Karen of Northern Thailand. Journal of Ethnobiology and Ethnomedicine, 
11(27), 1-13. DOI: https://doi.org/10.1186/s13002-0150011-9

Tariq, A., Mussarat, S., Adnan, M., Allah, E. F. A., Hashem, A., Alqarawi, A. A., \& Ullah, R. (2015). Ethnomedicinal Evaluation of Medicinal Plants Used against Gastrointestinal Complaints. BioMed Research International, 2015, 1-14.

DOI: https://doi.org/10.1155/2015/892947

Torres-Avilez, W., Medeiros, P. M. De, \& Albuquerque, U. P. (2016). Effect of Gender on the Knowledge of Medicinal Plants: Systematic Review and MetaAnalysis. Evidence-Based Complementary and Alternative Medicine, 2016, 1-13. https://doi.org/10.1155/2016/6592363

Tugume , P., Kakudidi, E.K., Buyinza, M., Namaalwa, J., Kamatenesi, M., Mucunguzi, P., \& Kalema J. (2016). Ethnobotanical Survey of Medicinal Plant Species Used by Communities Around Mabira Central Forest Reserve, Uganda. Journal of Ehtnobiology and Ethnomedicine, 12(5), 1-28. DOI: https://doi.org/10.1186/s13002-0150077-4.

Wildayati, T., Lovadi, I., \& Linda, R. (2016). Etnomedisin Penyakit Dalam pada Suku Dayak Tabun di Desa. Jurnal Protobiont, 4(3), 1-7. https://doi.org/10.26418/protobiont.v4i3 .13222

Yusro, F., Mariani, Y., Diba, F., \& Ohtani, K. (2014). Inventory of Medicinal Plants for Fever Used by Four Dayak Sub Ethnic in West Kalimantan, Indonesia. Kuroshio Science, $\quad 8(1), \quad 33-38$. https://pdfs.semanticscholar.org/85de/a1 079c6fb510e349c126eed288aeb485162 b.pdf?_ga $=2.237937280 .1828213471 .15$ 61974200-652424871.1561974200

Yusro, F., Mariani, Y., \& Wardenaar, E. (2019). Pemanfaatan Tumbuhan Obat untuk Mengatasi Gangguan Sistem Pencernaan oleh Suku Dayak Iban: Studi Kasus di Kabupaten Kapuas Hulu Kalimantan Barat. Jurnal Borneo Akcaya, 5(1), 58-72. http://jurnallitbang.kalbarprov.go.id/index.php/litba ng/article/download.

Yusro, F., Pranaka, R., Budiastutik, I., \& Mariani, Y. (2020). Diversity of Medicinal Plants Used by Traditional Healers of Dayak Desa Tribe in the Villages of Kebong and Merpak, Sintang Regency. Jurnal Biologi Tropis, 20(3), 329 - 339. DOI: https://doi.org/10.29303/jbt.v20i3.2010. 